\title{
Trophic interaction between topmouth gudgeon (Pseudorasbora parva) and the co-occurring species during summer in the Dniprodzerzhynsk reservoir
}

\author{
A.V. Didenko ${ }^{(1), \star}$, S.V. Kruzhylina ${ }^{(1)}$ \\ Received January 29, 2015 \\ Revised April 6, 2015 \\ Accepted April 21, 2015
}

\section{ABSTRACT}

Key-words: Dnieper reservoirs, topmouth gudgeon, invasive species, fish diets, trophic relationships
Topmouth gudgeon, Pseudorasbora parva is the most common invasive fish in Europe, which can compete with the juveniles of valuable commercial fishes. The goal of this work is to study the diet of topmouth gudgeon and trophic relationships with some native fishes inhabiting the littoral zone of the Dniprodzerzhynsk reservoir. The obtained relatively low values of diet overlaps between topmouth gudgeon and other co-occurring cyprinids such as juvenile roach, Rutilus rutilus; silver bream, Blicca bjoerkna; rudd, Scardinius erythrophthalmus; Prussian carp, Carassius gibelio and bleak, Abramis brama, indicate that it is not a serious food competitor for them, especially commercially valuable ones. On the contrary, high diet overlaps were observed among some native cyprinids such as juvenile roach, silver bream, rudd, and bleak. The major prey items of topmouth gudgeon were Chydorus sphaericus and chironomids, whereas other cyprinids selected Bosmina spp. This peculiarity may be due to different vertical distributions of these fish in the littoral zone of the reservoir, where topmouth gudgeon inhabit near-bottom water layers, where they preyed on near-bottom and benthic zooplankters and chironomids, while juvenile roach, silver bream, rudd, and juvenile and adult bleak live in higher water layers, where they preyed on pelagic zooplankton.

\section{RÉSUMÉ}

Interaction trophique entre le Pseudorasbora (Pseudorasbora parva) et les espèces coexistantes durant l'été dans le réservoir de Dniprodzerjynsk

\begin{abstract}
Mots-clés : réservoir du Dniepr, Pseudorasbora, espèce envahissante, alimentation de poissons,

Le Pseudorasbora, Pseudorasbora parva, est le poisson le plus envahissant en Europe, qui peut entrer en compétition avec les juvéniles de poissons de valeur commerciale localement. Le but de ce travail est d'étudier le régime alimentaire du Pseudorasbora et ses relations trophiques avec certains poissons indigènes qui habitent la zone littorale du réservoir de Dniprodzerjynsk. Les valeurs relativement faibles des chevauchements alimentaires obtenues entre le Pseudorasbora et d'autres cyprinidés tels que les juvéniles du gardon, Rutilus rutilus; de la brème bordelière, Blicca bjoerkna; du rotengle, Scardinius erythrophthalmus, du carassin argenté, Carassius gibelio et de la brème, Abramis brama, indiquent que ce n'est pas un concurrent alimentaire important pour eux, en particulier ceux ayant
\end{abstract}

(1) Institute of Fisheries of the National Academy of Agrarian Sciences of Ukraine, 135, Obukhivska St., 
relation trophique une valeur commerciale. Par contre, des chevauchements de régime importants ont été observés chez certains cyprinidés indigènes comme le gardon juvénile, la brème bordelière, le rotengle, et la brème. Les principales proies du Pseudorasbora sont Chydorus sphaericus et des chironomes, alors que les autres cyprinidés sélectionnent Bosmina spp. Cette particularité peut être due à différentes distributions verticales de ces poissons dans la zone littorale du réservoir, où le Pseudorasbora habite les couches d'eau près du fond, où il se nourrit près du fond de zooplancton benthique et de chironomes tandis que le gardon juvénile, la brème bordelière, le rotengle et les juvéniles et adultes d'ablette vivent dans les couches d'eau supérieures, où ils se nourrissent de zooplancton pélagique.

\section{INTRODUCTION}

Biological invasions are human induced environmental changes, which represent a threat to native fauna and flora (Vitousek et al., 1996). Species invasion is one of the leading mechanisms of global environmental change, particularly in freshwater ecosystems (García-Berthou et al., 2005). The invasion of alien species in aquatic environments is considered to be a global phenomenon, which attracts great interest. When exotic taxa invade communities of species that have co-evolved over long periods, the equilibrium between native species may be disrupted (Bo et al., 2012). The effects of non-native species can include predator-prey relationship, competition for food and habitat, hybridization between native and non-native species, etc. (Clarkson et al., 2005; Dietrich et al., 2006; Bampfyde and Lewis, 2007).

Currently, one of the most common and widespread invasive fish in Europe is topmouth gudgeon, Pseudorasbora parva (Temmnick et Schlegel, 1846), the native range of which includes the drainages of large Asian rivers such as the Amur, Yangtze, Huang He, water bodies of Japan, the Korean peninsula and Taiwan (Berg, 1949; Bănărescu, 1999; Kottelat and Freyhof, 2007). This species was accidentally introduced in Europe by the delivery of juvenile Chinese carps and was first registered in Romania in 1961 (Bănărescu, 1999). In Ukrainian waters, topmouth gudgeon has been observed since 1972 - in the Danube delta and Dniester (Kozlov, 1974). Since then, this species has significantly increased in population size and successfully established in many inland water bodies across Europe (Pinder et al., 2005; Kottelat and Freyhof, 2007).

The wide distribution of topmouth gudgeon in Europe and the high abundances reached, suggests a potentially high impact on native fish communities and other aquatic organisms (Declerck et al., 2002). Topmouth gudgeon compete with the juveniles of valuable commercial fishes for food and habitats as well as prey on their eggs and larvae (Kozlov, 1974). They also consume large zooplanktonic organisms in large amounts resulting in an increase in phytoplankton and an acceleration of the eutrophication of water bodies (Adamek and Sukop, 2000).

Currently, there is sufficient information on different aspects of topmouth gudgeon biology in European water bodies, including its diet and food preferences (Rosecchi et al., 1993; Wolfram-Wais et al., 1999; Hliwa et al., 2002; Bo et al., 2012; Záhorská et al., 2013); however studies of the trophic relationships between this invader and native species are usually limited by small ponds (Declerck et al., 2002; Britton et al., 2010; Jackson and Britton, 2013). Topmouth gudgeon has been studied insufficiently in Ukraine (Kotovskaya and Khristenko, 2013; Boltachev et al., 2006). For example, little information is available on the biology of this species in large water bodies such as the Dnieper reservoirs, which are important for commercial and recreational fisheries in Ukraine, where this invader arrived at the end of 1980s (Suhoyvan and Vyatchanina, 1989). Therefore, the goal of this work is to study the diet of topmouth gudgeon and its trophic relationships with some native fishes and, in particular, the juveniles of commercially valuable species, especially roach, with which they can co-occur. 


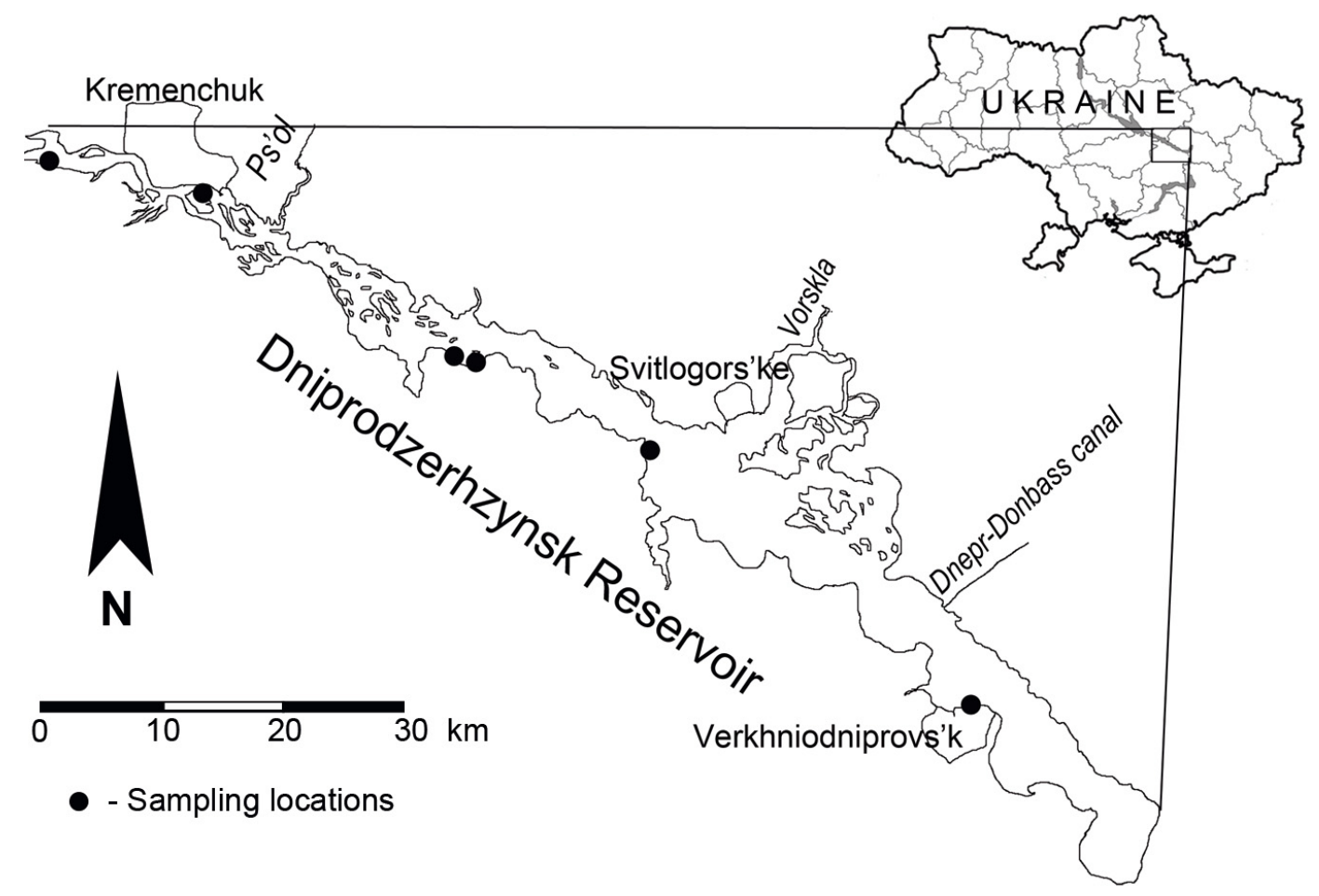

Figure 1

Locations of sample sites in the Dniprodzerzhynsk reservoir, Dnieper River, Ukraine.

\section{MATERIALS AND METHODS}

\section{> STUDY AREA}

The Dniprodzerzhynsk Reservoir is one of six Dnieper reservoirs, which was created between 1963 and 1965. The water body covers an area of $567 \mathrm{~km}^{2}$ (Denisova et al., 1989) and is located partially on the territory of Dnipropetrovsk, Poltava, and Kirovograd Oblasts (regions) of Ukraine. It has a length of $114 \mathrm{~km}$, maximum width of $20 \mathrm{~km}$, average depth of $4.3 \mathrm{~m}$, and maximum depth of $16 \mathrm{~m}$ (Denisova et al., 1989). When the reservoir is full, the area with depths less than $1 \mathrm{~m}$ composes $17 \%$ of its total area, while the total area of shallow waters with depths less than $2 \mathrm{~m}$ is $31 \%$ (Grynzhevskiy, 1998).

\section{> DATA COLLECTION}

Data were collected from six sampling sites in the littoral zone of the Dniprodzerzhynsk reservoir in August 2013 (Figure 1). The sampling sites were selected based on large numbers of topmouth gudgeon and juvenile roach, Rutilus rutilus L., an important commercial species in the reservoir, the annual catch of which according to the official statistics of 2000-2011 was within 150-195 tonnes (Buzevich and Didenko, 2012). All of the sampling sites had similar habitats with maximum depths from $1.0 \mathrm{~m}$ to $1.4 \mathrm{~m}$, sandy bottoms and little aquatic vegetation. Fish were caught in the littoral zone between 9:00 to 12:00 using a beach seine made of the mill sieve gauze ( $10 \mathrm{~m}$ long $\times 1 \mathrm{~m}$ high with $1.0 \mathrm{~mm}$ bar mesh size). The area of seine hauls depended on the water depth and bank steepness and ranged from approximately 20 to $80 \mathrm{~m}^{2}$. At least 20 topmouth gudgeon and 10 fish of the most abundant co-occurring species, if available, were collected for further analysis from each sampling site. Zooplankton samples were taken simultaneously with fish collection at the same sites using a conical plankton net (opening diameter $25 \mathrm{~cm}$, mesh size $150 \mu \mathrm{m}$ ) by vertically hauling it from the bottom to the 
water surface. Five zooplankton hauls were taken at different locations within each sampling sites and mixed together. Fish and zooplankton samples were preserved in $4 \%$ formalin solution and processed later in the laboratory.

In the laboratory, fish were sorted according to species, measured (standard length, SL) to the nearest $1 \mathrm{~mm}$, weighed to the nearest $0.01 \mathrm{~g}$ using an electronic balance and eviscerated. Gut contents were weighed to the nearest $0.001 \mathrm{~g}$ using a torsion balance (wet weight) and then examined under a binocular microscope in a counting chamber. Food items were identified to the highest resolution possible level and counted. Relatively large prey organisms were weighed on a torsion balance, if possible. Chironomid larvae were measured and their wet weights were calculated using published length-weight relationships (Ostrovskiy, 1983). For zooplankton organisms, the lengths of at least 20 individuals of each identified taxa were measured with an ocular micrometre. The dry weights of zooplankton organisms were estimated using published length-dry weight regression relationships (McCauley, 1984; Culver et al., 1985; Watkins et al., 2011). The obtained dry weight values of prey organisms were transformed into wet weight values using wet weight/dry weight conversion factors of 0.15 for zooplanktonic crustaceans (USEPA, 2010) and 0.1 for rotifers (Doohan, 1973) except Asplanchna, for which a factor of 0.039 was used (Dumont et al., 1975).

Gut content such as detritus, phytoplankton, plant debris, sand and unidentified remains were reported as non-animal food and their weights were calculated by subtracting the calculated weights of prey organisms from the total gut content weight.

Invertebrates from zooplankton samples were identified to the lowest possible level and counted under a binocular microscope in a counting chamber. Zooplankton abundance data were expressed in density (ind. $L^{-1}$ ).

\section{$>$ DATA ANALYSIS}

Fish species from different sampling sites were pooled and the following indices were used to describe their diets: frequency of occurrence of prey items (the percentage of non-empty stomachs containing a particular prey type) and their percentages by weight. In addition, topmouth gudgeon were divided into three size groups: $18-39 \mathrm{~mm}(n=87), 40-59 \mathrm{~mm}$ $(n=31), 60-83 \mathrm{~mm}(n=23)$ and the diet compositions of different size groups were examined separately.

The mean percentages of zooplankters in the environment were calculated from pooled zooplankton abundance data from different sampling sites.

Prey selectivity of zooplankton organisms was estimated using the Ivlev's electivity index (Ivlev, 1961):

$$
E_{i}=\left(r_{i}-p_{i}\right) /\left(r_{i}+p_{i}\right), \text { where }
$$

$r_{i}$ - percent number of prey $i$ in the stomach content;

$p_{i}$ - percent number of prey $i$ in the environment.

Linear regression was used to find the relationships between the length of topmouth gudgeon and the percentage of zooplankters and chironomids in their gut contents.

Diet overlap index (DOI) was calculated according to Shorygin's (1952) formula:

$$
\mathrm{DOI}=\sum_{i=1}^{n} \operatorname{minimum}(a, b), \text { where }
$$

$a$ - percent weight of a given prey item in the diet of species A;

$b$ - percent weight of a given prey item in the diet of species $B$.

This index ranges from $0 \%$ (no overlap) to $100 \%$ (complete overlap). Diet overlap was considered significant if DOI $\geqslant 60$ (Wallace, 1981). Diet overlaps were calculated based on all prey organisms excluding detritus, phytoplankton, plant debris, sand, and unidentified remains. These indices were calculated for all possible pairs of the most abundant fish species and additionally between juvenile roach and different size groups of topmouth gudgeon. 


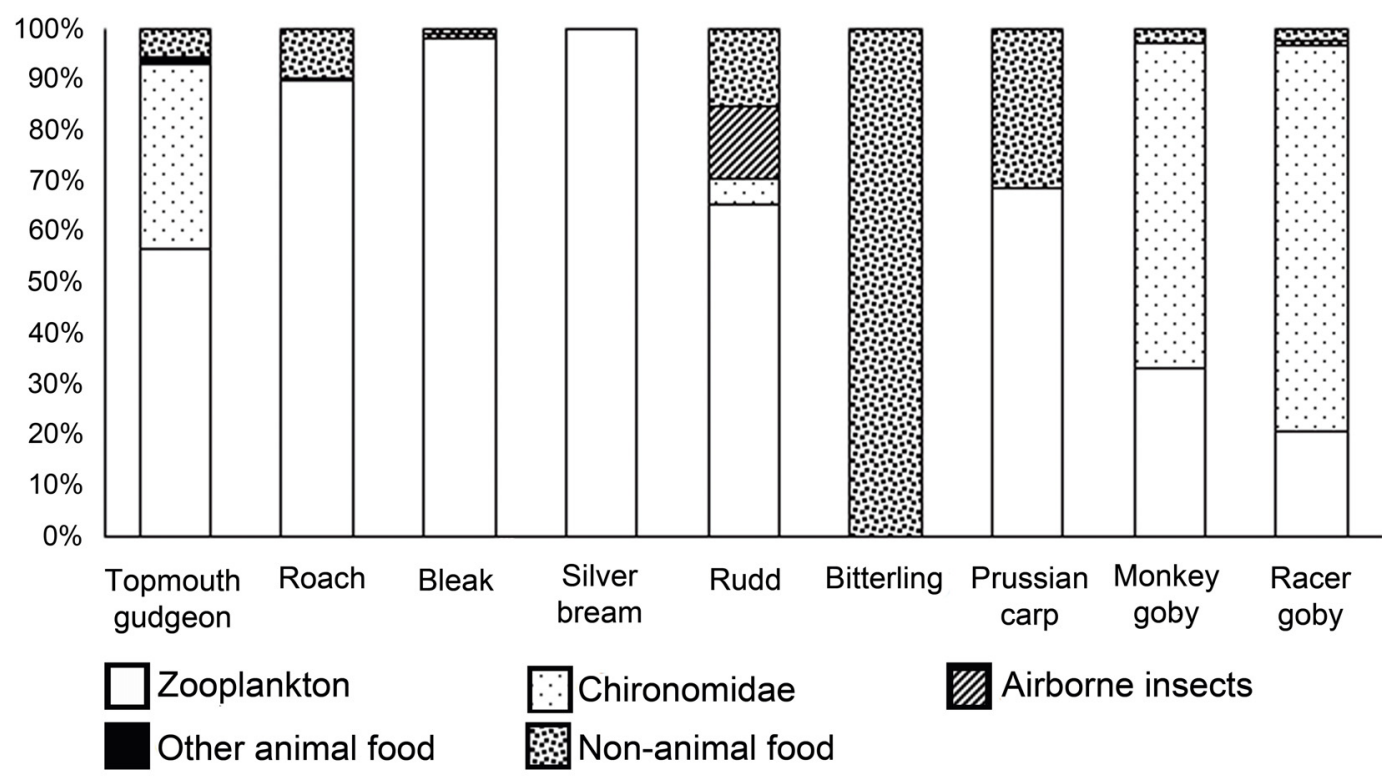

Figure 2

Gut contents of topmouth gudgeon and some co-occurring species in the littoral zone of the Dniprodzerzhynsk reservoir in August.

\section{RESULTS}

The co-occurring fish species in the studied sampling sites included juvenile and/or adult small sized: bitterling, Rhodeus amarus (Bloch, 1782), $(41.83 \%$ of the total number of all fish caught); topmouth gudgeon (15.05\%); bleak, Alburnus alburnus (L.), (14.22\%); roach (12.89\%); monkey goby, Neogobius fluviatilis (Pallas, 1814), (3.69\%); rudd, Scardinius erythrophthalmus (L.), (3.56\%); Prussian carp, Carassius gibelio (Bloch, 1782), (2.55\%); perch, Perca fluviatilis L., (2.40\%); chub, Squalius cephalus (L.), (1.13\%); racer goby, Neogobius gymnotrachelus (Kessler, 1857), (1.02\%); silver bream, Blicca bjoerkna (L.), (0.65\%); Dnieper chub, Petroleuciscus borysthenicus (Kessler, 1859), (0.56\%); round goby, Neogobius melanostomus (Pallas, 1814), (0.26\%); western tubenose goby, Proterorhinus semilunaris (Heckel, 1837), (0.09\%); spined loach, Cobitis taenia L., (0.06\%); bream, Abramis brama (L.), (0.01\%); and asp, Aspius aspius (L.), (0.01\%). Of them, roach, rudd, bream, silver bream, asp, Prussian carp, and perch are commercial species in the reservoir. Racer goby and round goby together with topmouth gudgeon are considered to be non-native species as they established here after the Dniprodzerzhynsk reservoir was created (Suhoyvan and Vyatchanina, 1989).

In total, the gut contents of 141 topmouth gudgeon $(37.9 \pm 1.4 \mathrm{~mm} ; 18-83 \mathrm{~mm}), 63$ roach $(46.3 \pm 2.3 \mathrm{~mm} ; 36-79 \mathrm{~mm}), 44$ Prussian carp $(38.5 \pm 1.6 \mathrm{~mm} ; 23-50 \mathrm{~mm}), 34$ bitterling $(39.2 \pm 2.2 \mathrm{~mm} ; 31-50 \mathrm{~mm}), 30$ silver bream $(28.1 \pm 0.5 \mathrm{~mm} ; 25-31 \mathrm{~mm}), 30$ rudd $(26.7 \pm$ $0.5 \mathrm{~mm}$; 23-29 mm), 48 bleak $(76.1 \pm 6.4 \mathrm{~mm}$; $39-100 \mathrm{~mm}), 48$ monkey goby $(37.0 \pm 3.1 \mathrm{~mm}$; $18-72 \mathrm{~mm}), 18$ racer goby $(39.7 \pm 1.9 \mathrm{~mm} ; 29-48 \mathrm{~mm})$ were analysed.

The most abundant prey items in the gut contents of topmouth gudgeon were zooplankton and chironomid larvae (Figure 2). Zooplankton played an important role in the diets of juvenile silver bream, roach and rudd as well as juvenile and small sized adult bleak. Chironomid larvae were important in the diets of two gobiids. Detritus and other non-animal food items composed the majority of the gut contents in bitterling and were sufficiently important in the diets of juvenile Prussian carp and rudd. Airborne insects were the most abundant in the gut contents of juvenile rudd.

At least 23 species/taxa of zooplankton organisms were identified in the diets of the studied fish species. They were divided into four groups: cladocerans, copepods, rotifers, and bryozoan statoblasts (Table I). Twenty-one species/taxa were observed in the diet of topmouth gudgeon, among which the dominating species by weight were cladocerans, among which 


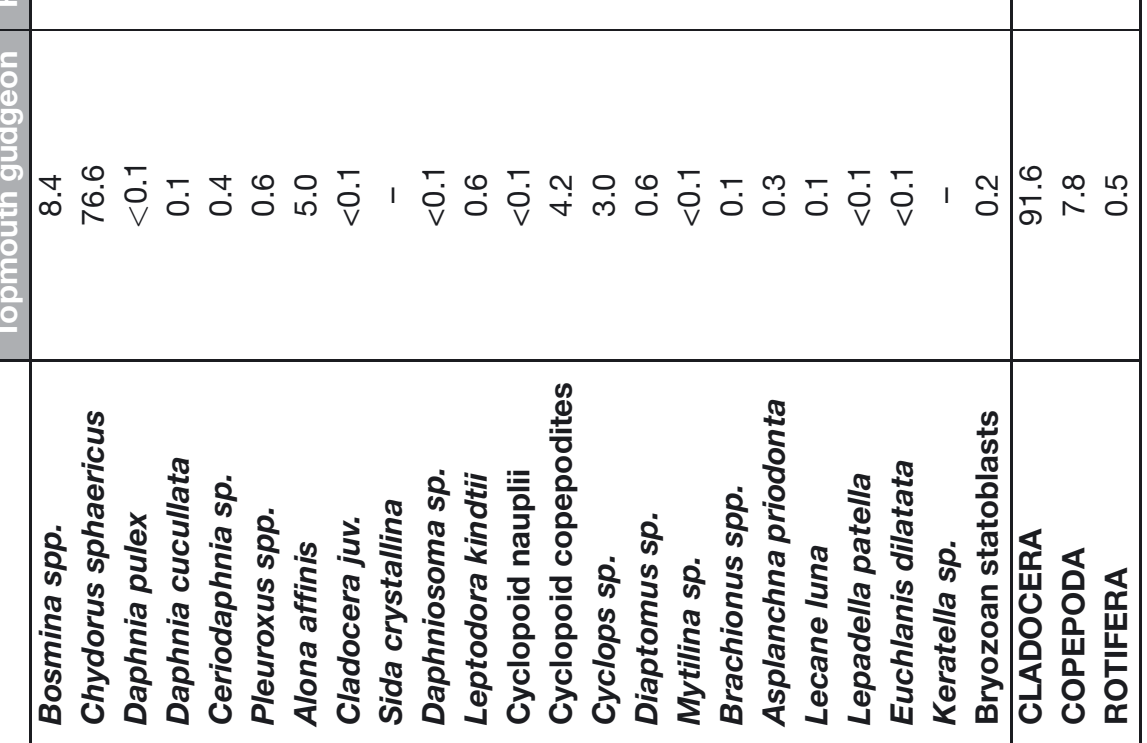




\section{Table II}

Diet composition of topmouth gudgeon of different size groups in the Dniprodzerzhynsk reservoir in August (\%FO - frequency of occurrence, $\% W$ - percentage by weight).

\begin{tabular}{|l|c|c|c|c|c|c|}
\cline { 2 - 7 } \multicolumn{1}{c|}{} & \multicolumn{1}{c|}{$18-39 \mathrm{~mm}$} & \multicolumn{2}{c|}{$40-59 \mathrm{~mm}$} & \multicolumn{2}{c|}{$60-83 \mathrm{~mm}$} \\
\cline { 2 - 7 } \multicolumn{1}{c|}{} & $\% \mathrm{FO}$ & $\% \mathrm{~W}$ & $\% \mathrm{FO}$ & $\% \mathrm{~W}$ & $\% \mathrm{FO}$ & $\% \mathrm{~W}$ \\
\hline Bosmina spp. & 58.6 & 8.0 & 12.9 & 0.4 & 21.7 & 0.4 \\
Chydorus sphaerucus & 78.2 & 74.4 & 6.5 & 7.9 & 17.4 & 0.4 \\
Daphnia pulex & 1.1 & $<0.1$ & - & - & - & - \\
Daphnia cucullata & - & - & - & - & 4.3 & 0.1 \\
Ceriodaphnia sp. & 9.2 & 0.4 & - & - & - & - \\
Pleuroxus spp. & 24.1 & 0.5 & 3.2 & 0.1 & 4.3 & $<0.1$ \\
Alona affinis & 44.8 & 4.8 & 6.5 & 0.3 & 8.7 & 0.2 \\
Daphniosoma sp. & 2.3 & $<0.1$ & - & - & - & - \\
Leptodora kindtii & 3.4 & 0.6 & - & - & - & - \\
Cladocera juv. & 2.3 & $<0.1$ & - & - & - & - \\
Mytilina sp. & 3.4 & $<0.1$ & - & - & - & - \\
Branchionus spp. & 13.8 & 0.1 & - & - & 4.3 & $<0.1$ \\
Asplanchna priodonta & 5.7 & 0.2 & 3.2 & 0.1 & 4.3 & 0.2 \\
Lecane luna & 20.7 & $<0.1$ & - & - & - & - \\
Lepadella patella & 14.9 & $<0.1$ & - & - & - & - \\
Euchlanis dilatata & 1.1 & $<0.1$ & - & - & - & - \\
Cyclopoid nauplii & 10.3 & $<0.1$ & - & - & - & - \\
Cyclopoid copepodites & 36.8 & 4.0 & - & - & 8.7 & 0.4 \\
Cyclops sp. & 3.4 & 0.8 & 19.4 & 6.7 & 4.3 & 0.7 \\
Diaptomus sp. & 1.1 & 0.5 & - & - & 4.3 & 0.2 \\
Bryozoan statoblasts & 5.7 & 0.1 & 9.7 & 0.1 & 17.4 & 0.1 \\
Bryozoans & - & - & 6.5 & 0.2 & 8.7 & 0.1 \\
Chironomidae larv. & 41.4 & 4.4 & 74.2 & 70.3 & 69.6 & 79.8 \\
Chironomidae pup. & 1.1 & $<0.1$ & 12.9 & 3.1 & 30.4 & 1.3 \\
Trichoptera & - & - & 3.2 & $<0.1$ & - & - \\
Airborne insects & 2.3 & $<0.1$ & 9.7 & 0.2 & 13.0 & 0.1 \\
Water mites & - & - & 3.2 & $<0.1$ & - & - \\
Dreissena polymorpha & - & - & 3.2 & 0.7 & 8.7 & 3.4 \\
Non-animal food & 92.0 & 1.0 & 87.1 & 9.8 & 100.0 & 12.5 \\
\hline
\end{tabular}

Chydorus sphaericus was the most abundant. The second abundant group were copepods (mainly copepodite stages of Cyclops sp.). Rotifers played a negligible role in the diet of topmouth gudgeon and the most important among them were Asplanchna priodonta.

Roach diet was comprised mostly of cladocerans, mainly Bosmina spp. and C. sphaericus. These prey items were also common in the diet of bleak and silver bream. Bosmina spp. also dominated in the gut content of rudd, while other important components in the diet of this species were Daphnia pulex and Pleuroxus spp. As for gobiids, copepods, mainly copepodite stages of Cyclops sp., significantly exceeded all other prey items in their diets.

Topmouth gudgeon of different size groups were characterized by different diet compositions (Table II). Zooplankton was more important in the diet of smaller fish and its share reduced with an increase in fish size. The most frequently encountered prey items in the smallest size group of topmouth gudgeon were $C$. sphaerucus, followed by Bosmina spp., chironomid larvae and cyclopoid copepodites. Chironomid larvae were the most frequently encountered prey items in the diets of all other size groups. Zebra mussel, Dreissena polymorpha, was an important prey item the largest size group of topmouth gudgeon.

The linear regression showed a negative relationship between the size of topmouth gudgeon and the content of zooplankton in their diets $(p<0.001)$. In contrast, a positive relationship was found between the share of chironomid larvae and fish length $(p<0.001)$. 


\section{Table III}

Ivlev's electivity indices on some zooplanktonic organisms for fishes inhabiting the littoral zone of the Dniprodzerzhynsk reservoir.

\begin{tabular}{|l|c|c|c|c|c|c|c|c|}
\cline { 2 - 8 } \multicolumn{1}{l|}{} & $\begin{array}{c}\text { Topmouth } \\
\text { gudgeon }\end{array}$ & Roach & Bleak & $\begin{array}{c}\text { Silver } \\
\text { bream }\end{array}$ & Rudd & $\begin{array}{c}\text { Prussian } \\
\text { carp }\end{array}$ & $\begin{array}{c}\text { Monkey } \\
\text { goby }\end{array}$ & $\begin{array}{c}\text { Racer } \\
\text { goby }\end{array}$ \\
\hline Bosmina spp. & -0.25 & 0.61 & 0.57 & 0.61 & 0.55 & -0.71 & -0.76 & - \\
Chydorus sphaericus & 0.66 & 0.06 & 0.30 & -0.10 & -0.18 & -0.08 & -0.37 & -0.07 \\
Daphnia pulex & -0.45 & 0.30 & - & - & 0.98 & -0.60 & - & - \\
Daphnia cucullata & -0.54 & - & - & - & - & -1.00 & - & - \\
Ceriodaphnia sp. & -0.62 & - & - & - & - & -0.97 & 0.41 & 0.43 \\
Pleuroxus spp. & 0.02 & -0.39 & - & - & - & -0.42 & - & - \\
Alona affinis & 0.58 & - & - & - & - & 0.96 & -0.10 & - \\
Leptodora kindtii & -0.86 & -0.93 & -0.83 & - & - & & -0.34 & - \\
Cyclopoid nauplii & -0.97 & -0.99 & -1.00 & - & - & -0.98 & - & - \\
Cyclopoid copepodites & -0.37 & -0.96 & - & - & - & -0.83 & 0.82 & 0.79 \\
Cyclops sp. & 0.00 & -0.89 & - & - & - & -0.89 & -0.11 & - \\
Brachionus spp. & -0.55 & -0.92 & - & -0.97 & - & -0.27 & - & - \\
Asplanchna priodonta & 0.62 & - & - & - & - & 0.33 & - & - \\
Euchlanis dilatata & -0.98 & - & - & - & - & & - & - \\
\hline
\end{tabular}

Table IV

Diet overlaps among some fish species inhabiting the littoral zone of the Dniprodzerzhynsk reservoir (without non-animal food), (\%).

\begin{tabular}{|l|c|c|c|c|c|c|c|}
\cline { 2 - 7 } \multicolumn{1}{c|}{} & Roach & Bleak & $\begin{array}{c}\text { Silver } \\
\text { bream }\end{array}$ & Rudd & $\begin{array}{c}\text { Prussian } \\
\text { carp }\end{array}$ & $\begin{array}{c}\text { Monkey } \\
\text { goby }\end{array}$ & $\begin{array}{c}\text { Racer } \\
\text { goby }\end{array}$ \\
\hline Topmouth gudgeon & 29.1 & 31.2 & 22.2 & 11.0 & 25.0 & 46.1 & 41.4 \\
Roach & & 96.5 & 92.5 & 67.4 & 20.8 & 4.5 & 1.1 \\
Bleak & & & 89.7 & 67.9 & 20.4 & 4.3 & 1.4 \\
Silver bream & & & 66.8 & 19.9 & 3.5 & 0.6 \\
Rudd & & & & 3.2 & 20.9 & 20.7 \\
Prussian carp & & & & & 5.5 & 2.0 \\
Monkey goby & & & & & & & 74.8 \\
\hline
\end{tabular}

The pooled zooplankton composition (\% by number) for six sampling sites was comprised of cladocerans: Bosmina spp. (20.8\%), Chydorus sphaericus (14.7\%), Ceriodaphnia sp. (2.6\%), Alona affinis (1.4\%), Leptodora kindtii (1.1\%), Pleuroxus spp. (0.4\%), Daphnia cucullata $(0.1 \%)$, Daphnia pulex (0.1\%), Daphnia longispina (0.1\%), Diaphanosoma brachyurum $(<0.1 \%)$; copepods: Cyclopoid nauplii (24.4\%), Cyclopoid copepodites (8.3\%), adult Cyclops sp. (2,0\%); and rotifers: Euchlanis dilatata (8.9\%), Filinia longiseta (6.7\%), Polyarthra spp. (4.3\%), Keratella cochlearis (2.4\%), Brachionus spp. (1.8\%), and Asplanchna priodonta $(0.1 \%)$.

The prey selectivity indices demonstrate that topmouth gudgeon positively selected such zooplankters as C. sphaericus and Alona affinis, was indifferent to Pleuroxus spp. and Cyclops sp. and avoided Bosmina spp. and other microcrustaceans (Table III). A. priodonta was positively selected among rotifers. Juvenile roach showed a positive selectivity for Bosmina spp. and $D$. pulex, were indifferent to $C$. sphaericus and avoided all other zooplankters. The similar picture was observed in bleak, silver bream, and rudd, which also positively selected Bosmina spp., and did not use other zooplankton organisms. Gobiids highly selected copepodite stages of copepods and in a lesser degree Ceriodaphnia sp. and avoided all other zooplankters.

No high diet overlaps were observed between topmouth gudgeon and other co-occurring fish species except with gobiids, which did show significant overlaps (Table IV). However, high diet overlaps were observed among native cyprinids, especially between roach and bleak, roach and silver bream, and bleak and silver bream. Following values of diet overlaps between 
roach and different size groups of topmouth gudgeon were obtained: $32.1 \%$ for $18-39 \mathrm{~mm}$, $8.9 \%$ for $40-59 \mathrm{~mm}$, and $1.4 \%$ for $60-83 \mathrm{~mm}$. Prussian carp juveniles did not have high diet overlaps with any examined species. The diets of two gobiids were very similar and significantly differed from those of cyprinids except topmouth gudgeon.

\section{DISCUSSION}

The diet of topmouth gudgeon in the Dniprodzerzhynsk reservoir was characterized by a higher diversity of prey items compared to other co-occurring fishes; however, it may be due to a larger sample size of this species. Nevertheless, stable isotope analysis carried out by Jackson and Britton (2013) in some UK ponds also demonstrated that topmouth gudgeon occupied a larger niche and had a more diverse diet than native species.

A shift in the diet composition of topmouth gudgeon from zooplankton to benthic animals with an increase in fish size was observed and this is consistent with the result obtained by Declerck et al. (2002) for Belgian shallow ponds, where the diet of the smallest size group of topmouth gudgeon $(<25 \mathrm{~mm}$ ) in late summer was comprised of cladoceran species (Bosmina, Chydoridae), whereas the gut content of the largest size group ( $>35 \mathrm{~mm}$ ) consisted of mainly chironomid larvae, while the intermediate size group $(25-35 \mathrm{~mm})$ was characterized by a mixed diet of cladocerans and chironomids.

In contrast to the present study, in Neusiedler See, Austria, YOY topmouth gudgeon fed almost exclusively on chironomids, while zooplankters were a negligible prey (Wolfram-Wais et al., 1999). Bosmina and Daphnia were major prey items in the diet of this fish in July and September in Kis-Balaton Reservoir, Hungary, whereas Chydorus played a non-significant role (Hliwa et al., 2002).

C. sphaericus seemed to be the most abundant and preferred prey of topmouth gudgeon among zooplankters in the Dniprodzerzhynsk reservoir during the study period. It may be related to the fact that this fish occupy the bentho-pelagic zone (Xie et al., 2001). Chydoridae remain in close contact with the substrate and thus they belong to the microbenthos rather than to the zooplankton (Vijverberg and Boersma, 1997). However, C. sphaericus can inhabit both bottom substrates including aquatic plants and the water column in the open water zone of eutrophic lakes (Whiteside, 1974; Williams, 1982). The fact that this zooplankter was represented in large quantities in the zooplankton samples ( $14.7 \%$ by number) taken from the water column may indicate that it also inhabited the pelagic zone of the littoral. $A$. affinis, which was also selected by topmouth gudgeon, belongs to Chydoridae as well and is a microbenthic crustacean (Whiteside, 1974). Of the zooplankton, C. sphaericus was more frequently encountered than Bosmina spp. in the diet of other bottom dwelling species such as Prussian carp and gobiids. This crustacean as well as $A$. affinis were probably more abundant on the bottom and in the near-bottom water layers, but separate sampling of zooplankton from different water layers is required to confirm this hypothesis.

The diets of pelagic cyprinid juveniles such as roach, bleak, silver bream, and rudd were dominated by pelagic crustaceans such as Bosmina spp., which included $B$. longirostris and $B$. coregoni. Both Bosmina and Chydorus are small-bodied cladocerans, which are more abundant in the pelagic zone of eutrophic temperate lakes and reservoirs than large-bodied species, especially with extensive cyanobacteria blooms (Vijverberg and Boersma, 1997), which were observed in the Dniprodzerzhynsk reservoir in late summer. Juvenile and subadult bleak, roach, and silver bream are typical zooplanktivores (Politou et al., 1993; Vašek et al., 2003; Vašek and Kubečka, 2004) and diet overlaps between them are very high and usually exceed 0.80 (Vašek et al., 2003). These fishes usually select large-sized microcrustaceans such as Daphnia spp. but will prey on small-bodied cladocerans when large-bodied ones are not available, especially in nearshore zones in late summer (Taleb et al., 1994; Pociecha and Amirowicz, 2003; Chappaz et al., 1999).

Copepods, despite being larger than small-bodied cladocerans, were rarely eaten by topmouth gudgeon and all other examined cyprinids but were positively selected by monkey and racer gobies. Copepods are more difficult to capture by actively foraging juvenile cyprinids 
(Winfield et al., 1983), whereas gobies are ambush predators (Kestrup and Ricciardi, 2009) and can probably catch them more easily (Adámek et al., 2010).

Chironomid larvae were important in the diet of not only topmouth gudgeon but also gobiids. While topmouth gudgeon in the Neusiedler See, Austria, fed mainly on epiphytic chironomids (Wolfram-Wais et al., 1999), those in the Dniprodzerzhynsk reservoir appeared to feed on benthic chironomids because virtually all middle and large size classes of this fish had sand in their gut contents, indicating that they collected their food from the sandy bottom, and the sampling sites had very scarce aquatic vegetation. Chironomids are common prey in the diet of monkey goby in the habitats, where amphipods and molluscs are not abundant (Kakareko et al., 2005; Grabowska et al., 2009). It is necessary to note that the percentages of chironomids in the gut contents of topmouth gudgeon and gobiids were not high compared to zooplankters probably because the sampled fishes inhabited sandy bottoms where chironomid biomass was relatively low.

The importance of zooplankton and chironomids in the diet of topmouth gudgeon is different in fish of different size groups. Larger fish have fewer zooplankters and more chironomids in their diet and vice versa for smaller fish.

Large sized topmouth gudgeon were the only fish, among the studied co-occurring species, to have small zebra mussel (approximately $1 \mathrm{~mm}$ in length) in their gut content and the proportion of zebra mussels in the diet increased with fish length. Furthermore, molluscs (gastropods) were observed in the diet of this fish in small lakes in China (Xie et al., 2001). Topmouth gudgeon were also the only species which fed on bryozoan colonies and Trichoptera larvae in the examined sampling sites; however, the proportion of these prey in the diet was negligible.

Relatively low diet overlap indices between topmouth gudgeon and other co-occurring species indicate that it is not a serious food competitor for native cyprinids, especially commercially valuable ones. Concurrently, high levels of food competition are observed among some native cyprinids such as juvenile roach, silver bream, rudd, and juvenile and adult bleak. This is due to the divergence in the selectivity of zooplankters between topmouth gudgeon and native cyprinids as well as the similarities in prey selectivity among these native species. Topmouth gudgeon preferred $C$. sphaericus and chironomids, whereas other native cyprinids selected Bosmina spp. Such a peculiarity may be due to different vertical distributions of these fish in the littoral zone of the reservoir, where topmouth gudgeon inhabit near-bottom water layers, while juvenile roach, silver bream, rudd, and juvenile and adult bleak live in higher water layers. However, fish sampling in different water layers would be advisable to test this hypothesis effectively. The diet of topmouth gudgeon was also different from that of Prussian carp, which preyed mainly on benthic $A$. affinis and consumed large amounts of detritus. The diet of juvenile rudd was somewhat different from that of other species because an important share in their gut contents belonged to airborne insects indicating that this fish inhabited near-surface water layers.

Significant diet overlaps were observed only between topmouth gudgeon and gobiids and was due to chironomid larvae, which were important prey items in all these fishes, and the highest diet overlaps were between monkey and racer gobies.

Bitterling were not used for the diet overlap assessment because their major diet items were non-animal food such as detritus and phytoplankton, which are common food for this species (Przybylski, 1996; Koutrakis et al., 2003) and are not supposed to be limiting in the reservoir. In contrast to this study, much higher overlaps of trophic niches were observed between topmouth gudgeon and roach (48-73\%) and between topmouth gudgeon and rudd (86-92\%) in small ponds in UK in a study based on stable isotope analysis (Jackson and Britton, 2013) and high diet overlaps result in the depressed somatic growth of roach (Britton et al., 2009). Rosecchi et al. (1993) reported that the diet of topmouth gudgeon was very similar to that of other littoral native fish species in Lake Mikri Prespa, Greece. However, lower diet overlaps between topmouth gudgeon and roach (26-44\%) were observed by Declerck et al. (2002) in shallow ponds in Belgium in late summer, where the first species fed mainly on zooplankton and chironomid larvae, whereas the diet of the second species was dominated by non-animal 
food such as phytoplankton, macrophyte fragments, and detritus. This could be due to the high proportion of low-energy food in the diet of roach that may be indicative of a competition induced niche shift to suboptimal food resources. The highest diet overlaps in the study of Declerck et al. (2002) were observed between topmouth gudgeon and the bottom-dwelling gudgeon, Gobio gobio (L.), which consumed mainly chironomid larvae.

Topmouth gudgeon in the littoral zone of a large reservoir such as the Dniprodzerzhynsk reservoir seem to occupy a very specific niche - the bentho-pelagic zone, at least in August when the data were collected, where they prey on near-bottom and benthic zooplankton and chironomid larvae allowing them to reduce the diet overlaps with the co-occurring native cyprinids, which probably occupy higher water layers (roach, silver bream, rudd, bleak) and prey on pelagic zooplankters or which live near the bottom (Prussian carp, bitterling) but fed on benthic zooplankton and non-animal food. However, the obtained results may be true only for late summer, when their prey such as zooplankton seem to have a high biomass, and for the distinct selected biotopes, where both topmouth gudgeon and juvenile roach were very abundant, and additional studies have to be carried out in different seasons and habitats.

\section{ACKNOWLEDGEMENTS}

The authors would like to thank Rebecca Stewart from Aquatic Ecology Unit, Lund University, for editing the manuscript.

\section{REFERENCES}

Adámek Z. and Sukop I., 2000. Vliv střevličky východni (Pseudorasbora parva) na parametry rybničniho prostředi. Biodiverzita ichtiofauny ČR, 3, 37-43.

Adámek Z., Jurajda P., Prášek V. and Sukop I., 2010. Seasonal diet pattern of non-native tubenose goby (Proterorhinus semilunaris) in a lowland reservoir (Mušov, Czech Republic). Knowl. Manag. Aquat. Ecosyst., 397, 02.

Bampfylde C. and Lewis M.A., 2007. Biological control through intraguild predation: Case studies in pest control, invasive species and range expansion. B. Math. Biol., 69, 1031-1066.

Bănărescu P., 1999. The freshwater fishes of Europe. Cyprinidae, Vol. 5/1, Aula Verlag Wiesbaden, 426 p.

Berg L.S., 1949. Freshwater fishes of the U.S.S.R. and adjacent countries, Part 2. Academy of Sciences of the USSR: Moscow, Leningrad, 325 p. (in Russian).

Bo T., Cammarata M., Candiotto A. and Fenoglio S., 2012. Trophic preferences of three allochthonous fishes in Bormida River (Alessandria, NW Italy). Hidrobiológica, 22, 195-200.

Boltachev A.R., Danilyuk O.N., Pakhorukov N.P. and Bondarev V.A., 2006. Distribution and certain features of the morphology and biology of the stone morocco Pseudorasbora parva (Cypriniformes, Cyprinidae) in the waters of Crimea. J. Ichthyology, 46, 58-63.

Britton J.R., Davies G.D. and Brazier M., 2009. Eradication of the invasive Pseudorasbora parva results in increased growth and production of native fishes. Ecol. Freshwat. Fish, 18, 8-14.

Britton J.R., Davies G.D. and Harrod C., 2010. Trophic interactions and consequent impacts of the invasive fish Pseudorasbora parva in a native aquatic foodweb: a field investigation in the UK. Biol. Invasions, 12, 1533-1542.

Buzevich I.Y. and Didenko A.V., 2012. The intensity of the exploitation of bream (Abramis brama L.) and roach (Rutilus rutilus L.) stocks in the Dniprodzerzhinsk reservoir. Naukovi Dopovidi NUBiP, 8, 1-12 (in Ukrainian).

Chappaz R., Doucende D. and Barthelemy R., 1999. Patterns of change in zooplankton community structures and the selective feeding of bleak, Alburnus alburnus (L.) in the Serre Ponçon dam between 1980 and 1996. Hydrobiologia, 391, 127-134.

Clarkson R.W., Marsh P.C., Stefferud S.E. and Stefferud J.A., 2005. Conflicts between native fish and nonnative sport fish management in the southwestern United States. Fisheries, 30, 20-27.

Culver D.A., Boucherle M.M., Bean D.J. and Fletcher J.W., 1985. Biomass of freshwater crustacean zooplankton from length-weight regressions. Can. J. Fish. Aquat. Sci., 42, 1380-1390. 
Declerck S., Louette G., De Bie T. and De Meester L., 2002. Patterns of diet overlap between populations of non-indigenous and native fishes in shallow ponds. J. Fish Biol., 6, 1182-1197.

Denisova A.I., Timchenko V.M., Nakhshina E.P., Novikov B.I., Ryabov A.K. and Bass Y.I., 1989. Hydrology and hydrochemistry of the Dnieper and its reservoirs Naukova Dumka, Kiev, 216 p. (in Russian).

Dietrich J.P., Morrison B.J. and Hoyle J.A., 2006. Alternative ecological pathways in the Eastern Lake Ontario food web - round goby in the diet of lake trout. J Great Lakes Res., 32, 395-400.

Doohan M., 1973. An energy budget for adult Brachionus plicatilis Müller (Rotatoria). Oecologia, 13, 351-362.

Dumont H.T, van de Velde I. and Dumont S., 1975. The dry weight estimate of biomass in a selection of Cladocera, Copepoda and Rotifera from the plankton, periphyton, and benthos of continental waters. Oecologia 19, 225-246.

García-Berthou E., Alcaraz C., Pou-Rovira Q., Zamora L., Coenders G. and Feo C., 2005. Introduction pathways and establishment rates of invasive aquatic species in Europe. Can. J. Fish. Aquat. Sci., 65, 453-463.

Grabowska J., Grabowski M. and Kostecka A., 2009. Diet and feeding habits of monkey goby (Neogobius fluviatilis) in a newly invaded area. Biol. Invasions, 11, 2161-2170.

Grinzhevsky M.V., 1998. Aquaculture of Ukraine (organizational-economical aspects), Vil'na Ukraina, Lviv, 364 p. (in Ukrainian).

Hliwa P., Martyniak A., Kucharczyk D. and Sebestyén A., 2002. Food preferences of juvenile stages of Pseudorasbora parva (Schlegel, 1842) in the KIs-Balaton Reservoir. Arch. Pol. Fish., 10 121-127.

Ivlev V.S., 1961. Experimental ecology of the feeding of fishes Yale University Press, New Haven, CT, $302 \mathrm{p}$.

Jackson M.C. and Britton J.B., 2013. Variation in the trophic overlap of invasive Pseudorasbora parva and sympatric cyprinid fishes. Ecol. Freshwat. Fish, 22, 654-657.

Kakareko T., Zbikowski J. and Zytkowicz J., 2005. Diel partitioning in summer of two syntopic neogobiids from two different habitats of the lower Vistula River, Poland. J. Appl. Ichthyol., 21, 292-295.

Kestrup Á. and Ricciardi A., 2009. Are interactions among Ponto-Caspian invaders driving amphipod species replacement in the St. Lawrence River? J. Great Lakes Res., 35, 392-398.

Kotovskaya A.A. and Khristenko D.S., 2013. Distribution and some peculiarities of biology of Pseudorasbora parva (Temminck et Schlegel, 1846) in the littoral of the Kremenchug Reservoir. Russian J. Biol. Invasions, 4, 156-160.

Kottelat M. and Freyhof J., 2007. Handbook of European freshwater fishes Publications Kottelat, Cornol, $646 \mathrm{p}$.

Koutrakis E.T., Kokkinakis A.K., Tsikliras A.C. and Eleftheriadis E.A., 2003. Characteristics of the European bitterling Rhodeus amarus (Cyprinidae) in the Rihios River, Greece. J. Fresh. Ecol., 18, 615-624.

Kozlov V.I., 1974. Topmouth gudgeon - Pseudorasbora parva (Schl.) - a new species of the ichthyofauna of the Dniester River basin. Vestink Zoologii, 1, 77-78 (in Russian).

McCauley E., 1984. The estimation of the abundance and biomass of zooplankton in samples. In: Downing J.A. and Rigler F.H. (eds.), A Manual for the assessment of secondary productivity in fresh waters. Blackwell Scientific Publishers, Boston, MA, 228-265.

Ostrovsky I.S., 1983. Length-weight relationships of Chironomus plumosus (Chironomidae, Diptera) larvae in different regions and the effects of sample preservation. Trudy Sevanskoi Hidrobiologicheskoi Stantsii 18, 164-171 (in Russian).

Pinder A.C., Gozlan R.E. and Britton J.R., 2005. Dispersal of the invasive topmouth gudgeon, Pseudorasbora parva in the UK: a vector for an emergent infectious disease. Fisheries Manag. Ecol. 12, 411-414.

Pociecha A. and Amirowicz A., 2003. An attempt to determine the share of zooplankton in food consumed by fish in the limnetic zone of a eutrophic dam reservoir. Oceanol. Hydrobiol. Stud., 32, 15-31.

Politou C.Y., Economidis P.S. and Sinis A.I., 1993. Feeding biology of bleak, Alburnus alburnus, in Lake Koronia, northern Greece. J. Fish Biol., 43, 33-43.

Przybylski M., 1996. The diet feeding pattern of bitterling Rhodeus sericeus amarus (Bloch) in the Wieprza-Krzna canal, Poland. Polskie Archiwum Hydrobiologii, 43, 203-212. 
Rosecchi E., Crivelli A. and Catsadorakis G., 1993. The establishment and impact of Pseudorasbora parva, an exotic fish species introduced into Lake Mikri Prespa (north-western Greece). Aquat. Conserv., 3, 223-231.

Shorygin A.A., 1952. Feeding and feeding relationships of the Caspian Sea fishes Pischepromizdat, Moscow, 267 p. (in Russian).

Suhoyvan P.G. and Vyatchanina L.I., 1989. Fish fauna and its productivity. In: Zimbalevskaya L.N., Suhoyvan P.G. and Chernogorenko M. (eds.), Invertebrates and fishes of the Dnieper River and its reservoirs Naukova dumka, Kiev, 136-173 (in Russian).

Taleb H., Reyes-Marchant P. and Lair N., 1994. Effect of vertebrate predation on the spatio-temporal distribution of cladocerans in a temperature eutrophic lake. Hydrobiologia, 294, 117-128.

USEPA, 2010. User's Guide and Technical Documentation KABAM Version 1.0, U.S. Environmental Protection Agency, Washington, DC, 123 p.

Vašek M. and Kubečka J., 2004. In situ diel patterns of zooplankton consumption by subadult/adult roach Rutilus rutilus, bream Abramis brama, and bleak Alburnus alburnus. Folia Zool., 53, 203-214.

Vašek M., Kubečka J. and Sed'a J., 2003. Cyprinid predation on zooplankton along the longitudinal profile of a canyon-shaped reservoir. Arch. Hydrobiol., 156, 535-550.

Vijverberg J. and Boersma M., 1997. Long-term dynamics of small-bodied and large-bodied cladocerans during the eutrophication of a shallow reservoir, with special attention for Chydorus sphaericus. Hydrobiologia, 360, 233-242.

Vitousek P. M., D’Antonio C.M., Loope L.L. and Westbrooks R., 1996. Biological invasions as global environmental change. Am. Sci., 84, 468-478.

Wallace Jr. R.K., 1981. An assessment of diet-overlap indexes. Trans. Am. Fish. Soc., 110, 72-76.

Watkins J., Rudstam L. and Holeck K., 2011. Length-weight regressions for zooplankton biomass calculations - A review and a suggestion for standard equations. Cornell Biological Field Station Publications and Reports. Bridgeport, NY, 17 p.

Whiteside M.C., 1974. Chydorid (Cladocera) ecology: Seasonal patterns and abundance of populations in Elk Lake, Minnesota. Ecology, 55, 538-550.

Williams J.B., 1982. Temporal and spatial patterns of abundance of the Chydoridae (Cladocera) in Lake Itasca, Minnesota. Ecology, 63, 345-353.

Winfield L.J., Peirson G., Cryer M. and Townsend C.R., 1983. The behavioural basis of prey selection by underyearling bream (Abramis brama (L.)) and roach (Rutilus rutilus (L.)). Freshwater Biol., 13, 139-149.

Wolfram-Wais A., Wolfram G., Auer B., Mikschi E. and Hain A., 1999. Feeding habits of two introduced fish species (Lepomis gibbosus, Pseudorasbora parva) in Neusiedler See (Austria), with special reference to chironomid larvae (Diptera: Chironomidae). Hydrobiologia, 408/409, 123-129

Xie S., Cui Y. and Li Z., 2001. Dietary-morphological relationships of fishes in Liangzi Lake, China. J. Fish Biol., 58, 1714-1729.

Záhorská E., Balážová M. and Šúrová M., 2013. Morphology, sexual dimorphism and size at maturation in topmouth gudgeon (Pseudorasbora parva) from the heated Lake Lichenskie (Poland). Knowl. Manag. Aquat. Ecosyst. 411, 07.

Cite this article as: A.V. Didenko and S.V. Kruzhylina, 2015. Trophic interaction between topmouth gudgeon (Pseudorasbora parva) and the co-occurring species during summer in the Dniprodzerzhynsk reservoir. Knowl. Manag. Aquat. Ecosyst., 416, 13. 